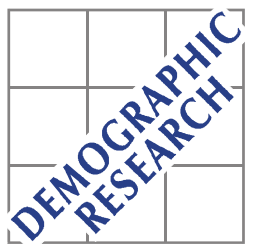

Demographic Research a free, expedited, online journal of peer-reviewed research and commentary in the population sciences published by the Max Planck Institute for Demographic Research Konrad-Zuse Str. 1, D-18057 Rostock · GERMANY www.demographic-research.org

DEMOGRAPHIC RESEARCH

VOLUME 21, ARTICLE 8, PAGES 215-234

PUBLISHED 18 AUGUST 2009

http://www.demographic-research.org/Volumes/Vol21/8/

DOI: $10.4054 /$ DemRes.2009.21.8

Research Article

\title{
Is Poland really 'immune' to the spread of cohabitation?
}

\section{Anna Matysiak}

(C) 2009 Anna Matysiak.

This open-access work is published under the terms of the Creative Commons Attribution NonCommercial License 2.0 Germany, which permits use, reproduction \& distribution in any medium for non-commercial purposes, provided the original author(s) and source are given credit.

See http:// creativecommons.org/licenses/by-nc/2.0/de/ 


\section{Table of Contents}

1 Introduction 216

2 Formation of non-marital unions in Europe: a brief overview of 217 the developments

3 Measurement of the incidence of cohabitation in Poland: Review 218 of problems

$4 \quad$ Data and method 219

$5 \quad$ Empirical findings 221

5.1 Cohabitation in Poland: Levels and trends 221

$5.2 \quad$ Permanency of cohabitation? 223

5.3 Diffusion of cohabitation to other social strata? 224

5.4 Cohabitation as a family arrangement? 227

$\begin{array}{lll}6 & \text { Conclusions and discussion } & 229\end{array}$

$\begin{array}{llr}7 & \text { Acknowledgements } & 230\end{array}$

$\begin{array}{ll}\text { References } & 231\end{array}$ 


\title{
Is Poland really 'immune' to the spread of cohabitation?
}

\author{
Anna Matysiak ${ }^{1}$
}

\begin{abstract}
Various data have constantly pointed out a low incidence of non-marital unions in Poland (at 1.4-4.9\% among all unions). In this paper we demonstrate that these data, coming exclusively from cross-sectional surveys, clearly underestimate the scale of the phenomenon. By exploiting data on partnership histories we show that young Poles have increasingly opted for cohabitation. Consequently, in the years 2004-2006, entries to cohabitation constituted about one third of all first union entries. Consensual unions have traditionally been seen as being more widespread among the lower social strata, but a clear increase in cohabitation has also been recently observed among groups with higher levels of educational attainment. Although the estimates of cohabitation incidence are far below those observed in Northern and Western Europe, our study suggests that Poland is not as 'immune' to the spread of consensual unions as it is commonly believed.
\end{abstract}

\footnotetext{
${ }^{1}$ Institute of Statistics and Demography (Unit of Demography), Warsaw School of Economics. Al. Niepodległości 164; 02-554 Warsaw. E-mail: amatys@sgh.waw.pl.
} 


\section{Introduction}

The literature claims that patterns of family formation in Poland are relatively traditional (Sobotka 2008, Sobotka and Toulemon 2008). Indeed, marriages in Poland are still contracted at relatively young ages, the incidence of divorce is low and out-ofwedlock births remain relatively uncommon (Hantrais 2005, Kotowska et al. 2008), despite observed trends toward delayed and deinstitutionalised family formation. Poles are strongly attached to the ideal form of a marital union with children (Pongracz and Spéder 2008), and express the most strongly negative attitudes towards changes in family formation patterns in the CEE (Stankuniene and Maslauskaite 2008).

Consistent with this view that traditional ideals about patterns of family formation persist in Poland, various data sources have constantly shown a low incidence of nonmarital cohabitation for that country; according to the National Population Census informal unions made up a mere $1.3 \%$ of all unions in 1988, $1.7 \%$ in 1995 and $2.2 \%$ in 2002 (Slany 2002, Fihel 2005). The Population Policy Acceptance Study as of 2001 gives an estimate of $1.4 \%$ (Kotowska et al. 2003) and the European Social Survey (2006) yields a value of $4.5 \%^{2}$. Half of the consensual unions are formed by never married (CSO 2003) while the proportions of cohabitants among young persons (aged 29 or less) are only slightly higher ${ }^{3}$ and fall well below what is found for many Northern and Western European countries (excluding the Mediterranean countries) (Andersson and Philipov 2002). In these parts of Europe cohabitation had already outdistanced direct marriage as the normative choice for a first union by the late 1980s. Similar finding has been established recently for Bulgaria, Russia and Hungary (Hoem et al. forthcoming) as well as for the Czech Republic (Sobotka et al. 2008).

The focus of this paper is on first unions in Poland with a special emphasis on nonmarital cohabitation. We demonstrate that the cross-sectional data used so far for assessing the incidence of consensual unions in Poland clearly underestimate the scale of this phenomenon. Taking advantage of retrospective data collected in 2006, covering women's full partnership histories, we show that young Polish women increasingly choose to cohabit before entering a marriage. Although consensual unions in Poland are still relatively rare by European standards, it is evident from our analysis that cohabitation has been spreading recently across all social strata.

\footnotetext{
${ }^{2}$ Based on the computations by the author of the study.

${ }^{3}$ For instance the National Population Census gives an estimate of $4.9 \%$ among all partnered persons aged 29 or less.
} 


\section{Formation of non-marital unions in Europe: a brief overview of the developments}

Informal unions are not a new phenomenon in post World War II Europe. Before the 1970s, however, they were largely statistically invisible. They were practised in some marginal sections of the society, i.e. among the poor who could not afford the marriage ceremony (Trost 1978, Villeneuve-Gokalp 1991), the separated who were legally not entitled to remarry (Haskey 2001), or surviving spouses who did not want to lose their pensions (Nazio and Blossfeld 2003). Only in a few cases did people choose to cohabit openly on a voluntary basis; in Sweden, for example, consensual unions could be found within avant-garde groups who manifested their resistance against societal and religious norms thusly (Trost 1978).

This situation started to change in the 1970s. In Northern (and later Western) Europe consensual unions were increasingly accepted and grew in popularity, particularly among the young forming their first unions. Gradually they replaced direct entry to traditional marriage as had been recognized by the state. For instance, in the Nordic countries and France the proportion of women entering cohabitation as their first union exceeded 80\% among cohorts born in the 1950s (Anderson and Philipov 2002). In Austria (Prskawetz et al. 2008), England and Wales (Sigle-Rushton 2008), and the Netherlands (Fokkema at al. 2008), where consensual unions started to spread slightly later, around $70 \%$ of first marriages contracted by women born in the 1960 s were preceded by cohabitation.

Given the developments in cohabitation in the Northern and Western countries, scholars have distinguished four stages for the diffusion of cohabitation, which describe transitions in union formation patterns (Prinz 1995, Kiernan 2002). In the first stage cohabitation is rare and is practised by marginal groups of the society. Over time it becomes more popular and is adopted by persons from the various social strata. Nevertheless, at this second stage of diffusion cohabitation is still of short duration and it functions mainly as a prelude to marriage or a trial period when the quality of the relationship is tested. It is often perceived as inappropriate environment for childbearing and hence is usually converted into marriage if pregnancy occurs. Gradually cohabitation starts to substitute for marriage: it lasts longer and becomes an acceptable arrangement for parenthood (third stage). Finally, in the fourth stage cohabitation and marriage turn out to be indistinguishable, which concludes the transition process.

In this context, Sobotka and Toulemon (2008) distinguish three important markers of this transition in union formation patterns:

1. Diffusion: cohabitation becomes practised on the larger scale and it spreads among persons from the various social strata, 
2. Permanency: it lasts longer and is less likely to be converted into marriage,

3. Cohabitation as a family arrangement: pregnancy ceases to be a reason for marriage and parenthood becomes more and more common among cohabiting couples.

Our study follows this schema: besides assessing the temporal change in the intensity of entering cohabitation and direct marriage we also verify whether (a) cohabitation has spread equally likely among people from the various social strata; (b) its rate of conversion into marriage has declined over time; (c) the propensity to legitimize a child conceived in cohabitation has declined.

\section{Measurement of the incidence of cohabitation in Poland: Review of problems}

The available estimates of the incidence of cohabitation as presented in Section 1 suggest that Poland remained largely 'immune' to the spread of non-marital unions. In this paper we argue that these estimates do not give a proper illustration of the development of the phenomenon for at least two reasons.

First, the existing estimates of cohabitation incidence are computed on the basis of cross-sectional data. In our opinion this type of data is not suitable to capture a phenomenon of limited duration, particularly if it is in the relatively early phase of diffusion. The changes in partnership behaviors can be more appropriately assessed with longitudinal data that allow researchers to trace cohabitation episodes of any duration and at different stages along an individual's life course.

The second problem may be rooted in the way interviewed respondents are asked about cohabitation. In Poland there is no well recognised word that would describe the fact of living together without being married in a neutral way. The term 'cohabitation' (pol. 'kohabitacja') is hardly understood (Slany 2002: 239) and it is not common to say 'we live in a partnership'. Instead, there exists a word 'concubinage' (pol. 'konkubinat') which has clearly negative connotations (Mynarska and Bernardi 2007: 539). Surveys often use at least one of these terms (e.g. National Population Census or Population Policy Acceptance Study). It is very likely that the use of an uncommon term or a term which is pejorative leads to the situation in which cohabiting respondents do not want to reveal the truth on the status of their union.

In this study we are fortunate to have access to data which overcome these problems. First, those we use are retrospective and cover women's past partnership, educational and fertility histories. This allows us to track any cohabitation episodes a 
person experienced instead of relying upon the computation of the proportions of persons cohabiting at a given time. Second, the information on cohabitation in the survey we use was gathered by asking partnered but unmarried respondents whether they resided with a partner. The unpopular word 'concubinage' was not mentioned, nor were any terms used like 'cohabitation' or 'partnership' which may be obscure for Polish respondents. We believe that this way of interviewing could have contributed to a higher accuracy of the collected data.

\section{Data and method}

The Employment, Family and Education Survey (EFES) which is used in this study took place in the fourth quarter of $2006^{4}$. It is a retrospective survey which provides us with monthly data on 3,000 life histories of women born 1966-1981. These women were $25-40$ at the time of the interview. The advantage of this observational design is that we have good information on union formation patterns for relatively young cohorts who formed their partnerships after the collapse of state socialism, i.e. in the period of a rapid transformation in family formation processes. The disadvantage is, however, that we have no data on the youngest cohorts, born in the 1980s, who were forming their partnerships in the 2000s, and very limited data on family-related behaviours in the years preceding 1989 when our respondents were relatively young (aged 8-23 in 1989).

In order to address our research objectives we estimate three single decrement piecewise-constant intensity regressions. The first two models describe the process of entry into cohabitation versus entry directly into marriage, with both events treated as competing risks. The process time in these regressions are the months elapsed since a woman turned fifteen years of age. The third model describes the process of converting cohabitation into marriage. Theoretically cohabitation may also end in union disruption, but this seems to be very uncommon in Poland. The number of break-downs among consensual unions in our sample is very low (69), making it difficult for us to model disruption of cohabitation. Nonetheless, we provide the reader with some descriptive data on the duration of cohabitation for all consensual unions as well as for unions that ended solely in a marriage in Section 5.2 in order to give a better overview on the duration of cohabitation.

\footnotetext{
${ }^{4}$ The survey was prepared at the Institute of Statistics and Demography (Warsaw School of Economics) under the project "Cultural and structural conditions of females' labour force participation in Poland" financed by the Ministry of Science and Higher Education and coordinated by Professor Irena E. Kotowska. For a general description of the survey see Kajcińska (2008).
} 
Several fixed- and time-varying covariates are allowed to shift the baseline hazards we specified. Among the time-constant covariates we include the educational level of the woman's mother and father as a proxy for her social background. The set of timevarying covariates comprises the calendar period, the woman's own educational attainment, her parity-and-pregnancy status, and her place of residence (urban/rural).

The calendar period is introduced in our model in order to capture the temporal change in the process of interest. The years 1985-2006 were divided into five intervals, the first of which separates the period of state socialism from that of a market economy. The entry risk is assumed to be constant within each interval, but may vary from one interval to the other.

The woman's educational level is another time-varying covariate incorporated in our analysis. Four educational levels are distinguished: primary, vocational, secondary, and tertiary. The first category covers women who completed only the compulsory education of eight years. Women with a vocational education are those who continued for further two years in order to get a vocational degree. The two categories, primary and vocationally educated, are collapsed into one in the models in which educational level is introduced in interaction with another covariate. The underlying reason is the low number of primary educated women. Another educational group distinguished are the secondary educated women that accomplished at least four years of education at the secondary level or even undertook post-secondary but non-tertiary education. Women who received a bachelor or master degree are classified as tertiary educated. Finally, those who were still studying were grouped into a separate category 'in education'.

The parity-and-pregnancy status accounts for the impact of conception on union formation. A woman is considered as childless and non-pregnant until nine months before she delivers her first child, as childless and pregnant during the time of the first pregnancy, and as a mother after she gives birth for the first time. Non-partnered women pregnant with the second or higher order child or women who delivered at least two children are also classified in the latter category since they are very few. We expect pregnancy to facilitate entry into a union with entry into a marriage in particular.

The place of residence (urban/rural) serves as an important control covariate. Other Polish data sources have shown that consensual unions are more likely to be formed in urban rather than rural areas due to the larger anonymity of urban life (Slany 2002, Fihel 2005).

We also introduce some interaction effects in our models. The first set of interactions includes interactions of selected covariates with educational level of a woman. This allows us to investigate whether cohabitation has been spreading equally among various social strata. In particular, we test whether the intensity of forming a consensual union or converting it into a marriage has been changing among women 
from all social strata at a similar rate. Likewise, we analyse whether the duration of cohabitation varies with respect to the educational level of a woman.

The second set of interactions includes an interaction between calendar period and parity-and-pregnancy status in the cohabitation-to-marriage model. In this way we verify whether pregnancy started to cease to be a reason for marriage in the process of cohabitation diffusion in Poland.

Finally, we estimate the competing transitions to cohabitation and direct marriage jointly, controlling for the same set of factors as described above (only main effects are considered). In the joint model the decrement type is introduced into the analysis as a time-constant covariate additionally to other risk factors. This technique has been described in detail in Hoem and Kostova (2008) and in the Appendix to Hoem et al. (forthcoming). It allows a direct comparison between the time trends regarding the entry into cohabitation versus the entry into a direct marriage, which means that we can verify whether cohabitation became more widespread than direct marriage at any time and whether the decline in direct marriage was compensated by an increase in the incidence of informal unions. We refer to the results of the joint model only where we present temporal developments in union formation (Section 5.1). In this part of our study we follow the recommendation of Hoem et al. (2009) and disregard differential impacts of other risk factors, which are then used only for purposes of standardisation.

\section{Empirical findings}

\subsection{Cohabitation in Poland: Levels and trends}

A simple descriptive analysis of first unions indicates that among women aged 25-40 in 2006 who ever entered a first union only $18 \%$ decided for cohabitation while the remaining $82 \%$ chose a direct marriage. There is thus no doubt that consensual unions are still relatively uncommon in Poland if compared to the Northern and Western European countries. Nonetheless, it is clear that cohabitation in Poland is a more attractive option for first union formation than the official statistics and other crosssectional data suggest. This is largely due to the fact that the retrospective character of our data allows us to track any cohabitation episodes experienced by the neverpartnered respondents to the EFES, i.e. it allows us to assess the level of ever cohabitation. In order to illustrate this phenomenon we computed additionally the proportion of cohabiting persons among those in first union in 2006; an indicator of the 
current cohabitation which is typically calculated based on cross-sectional data ${ }^{5}$. Amounting to $6.3 \%$ this indicator falls three times below the level of ever cohabitation.

The indicator of ever cohabitation of $18 \%$ constitutes an average measure of cohabitation incidence in the period 1985-2006. However, we shall be interested in the temporal change in the intensity of entering a non-marital union and a direct marriage if we want to assess patterns in cohabitation diffusion. These trends are presented in Figure 1. They are obtained from the joint analysis of the two competing processes. This means that the trends in union formation patterns are computed net of any compositional changes in educational level of women, their place of residence and parity-and-pregnancy statuses. Our results apparently illustrate a change in the first union formation patterns. It is manifested in a clear decline in the entry into a direct marriage, which has been taking place already since the second half of the 1980s, and a parallel increase in the incidence of cohabitation since the early 1990s. In the period 1990-1994 entries to cohabitation constituted only $12 \%$ of all unions formed. By the years 2004-2006 this percentage has tripled. Overall, it is clear from the data that the importance of cohabitation as a normative choice for the first union has largely increased. Although it is still more common for the young Poles to marry directly, the gap between the intensity of entering a direct marriage and a consensual union has greatly diminished.

\footnotetext{
${ }^{5}$ Note however that our indicator refers to first unions only and women in higher order unions are excluded from computations. Estimates of cohabitation from cross-sectional surveys usually do not distinguish between first and higher order unions.
} 
Figure 1: Trends in (standardised) relative risks of first union formation, by type of union. Poland 1985-2006. Joint competing risk model

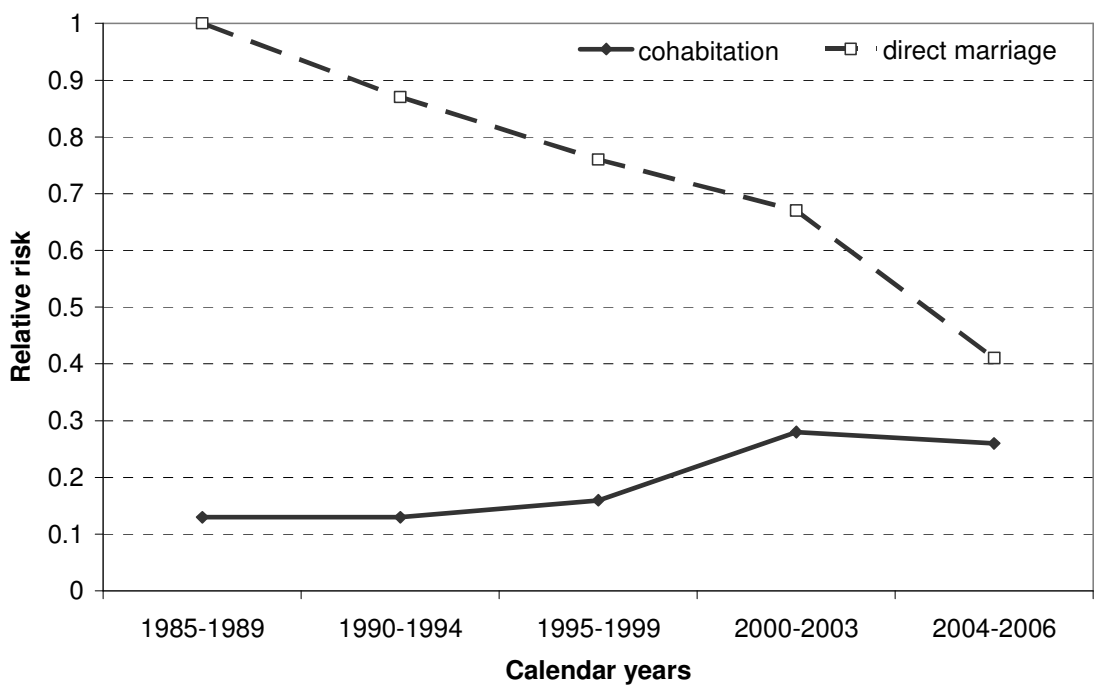

Note: The figure refers to women born 1966-1981. The risks are standardised for current age, woman's educational level, parity-andpregnancy status, place of residence, mother's and father's educational levels

Source: computations by Jan M. Hoem.

\subsection{Permanency of cohabitation?}

Given the relatively low general incidence of cohabitation in Poland one could expect cohabitation episodes to be rather short and the intensity of converting them into a marriage to be high. Our findings, however, do not support this view. Over the analyzed period, only $8 \%$ of cohabitants exited a consensual union within six months, and only $19 \%$ within one year since its formation (Table 1). The median duration of a consensual union was 3 years. Women were demonstrably more likely to end their cohabitation with a marriage than through a disruption. For instance, among consensual unions lasting less than 3 years, $80 \%$ were converted into a marriage and only $20 \%$ were disrupted. Overall, our results suggest that the women who decide for cohabitation in Poland typically remain in this state for a few years. It is also notable that the intensity of ending the consensual union, either with marriage or disruption, has been decreasing over time and in the years 2000-2006 it was by 30\% lower than in the late 1980s. The 
risk of converting a cohabitation into a marriage declined even more strongly, i.e. by $40 \%$.

\section{Table 1: Descriptive statistics on the duration of cohabitation}

\begin{tabular}{cccc}
\hline $\begin{array}{c}\text { time t } \\
\text { (in months) }\end{array}$ & $\begin{array}{c}\text { exited from } \\
\text { cohabitation by time } \mathbf{t} \\
\text { among those still in } \\
\text { cohabitation }\end{array}$ & $\begin{array}{c}\text { Proportion of women who: } \\
\text { converted cohabitation } \\
\text { into marriage by time t } \\
\text { among those still in } \\
\text { cohabitation }\end{array}$ & $\begin{array}{c}\text { converted cohabitation } \\
\text { into marriage among all } \\
\text { who exited } \\
\text { cohabitation }\end{array}$ \\
\hline 6 & 0.92 & 0.92 & 0.92 \\
12 & 0.81 & 0.83 & 0.91 \\
24 & 0.64 & 0.69 & 0.85 \\
36 & 0.49 & 0.57 & 0.81 \\
48 & 0.40 & 0.49 & 0.80 \\
60 & 0.36 & 0.46 & 0.79 \\
\hline
\end{tabular}

Source: author's computations.

\subsection{Diffusion of cohabitation to other social strata?}

Two hypotheses were developed in the literature as regards the role of education in the spread of consensual unions. The first views cohabitation as a fashion that expanded from the top of the social hierarchy to the bottom. Such pattern of modern cohabitation diffusion was found in the Netherlands (de Feijter 1991 quoted in Sobotka 2008), Italy (Rosina and Fraboni 2004), and Spain (Baizán, Aassve, and Billari 2003). The second competing hypothesis suggests that cohabitation started among the disadvantaged members of the society. This was in fact the case in some Western and Northern European countries as well as in the United States. Recent studies point out a negative educational gradient in cohabitation also in some of the Central and Eastern European countries (e.g., Spéder 2005 for Hungary, Koytcheva and Philipov 2008 for Bulgaria, Hoem et al. 2009 for Romania).

Our results undoubtedly suggest that cohabitation in Poland is more widespread among the lower social strata. This finding is consistent with those of Slany (2002: 184194) and Fihel (2005) who analysed data from the Mikrozensus 1995 and the National Population Census 2002 respectively. Polish cohabitants are likely to possess lower levels of education, while the more highly educated tend to marry directly. Furthermore, women with university degrees who cohabit progress to marriage more 
quickly than similar but lower educated women; this shortens the duration of their consensual unions (Table 2 and Figure 2).

Table 2: $\quad$ Relative risks for education in single decrement models

\begin{tabular}{|c|c|c|c|}
\hline & \multicolumn{2}{|c|}{ Mode of union entry $^{\text {a) }}$} & \multirow{2}{*}{$\begin{array}{c}\text { Conversion of } \\
\text { cohabitation to } \\
\text { marriage }^{\text {b) }}\end{array}$} \\
\hline & cohabitation & direct marriage & \\
\hline \multicolumn{4}{|l|}{ Education } \\
\hline in education & 0.73 & 0.39 & 0.82 \\
\hline tertiary & 1 & 1 & 1 \\
\hline secondary & 1.21 & 0.76 & 0.89 \\
\hline vocational & 1.4 & 0.76 & 0.79 \\
\hline primary or lower & 1.35 & 0.55 & 0.57 \\
\hline
\end{tabular}

Notes: ${ }^{\text {a) - }}$ standardized for current age, calendar period, parity-and-pregnancy status, place of residence, mother's and father's educational levels; ${ }^{\text {b) }}$ standardized for current age, calendar period, parity-and-pregnancy status, place of residence, mother's and father's educational levels and union duration.

Source: author's computations.

Figure 2: Hazard rate of conversion from cohabitation to marriage, by educational level. Poland 1985-2006

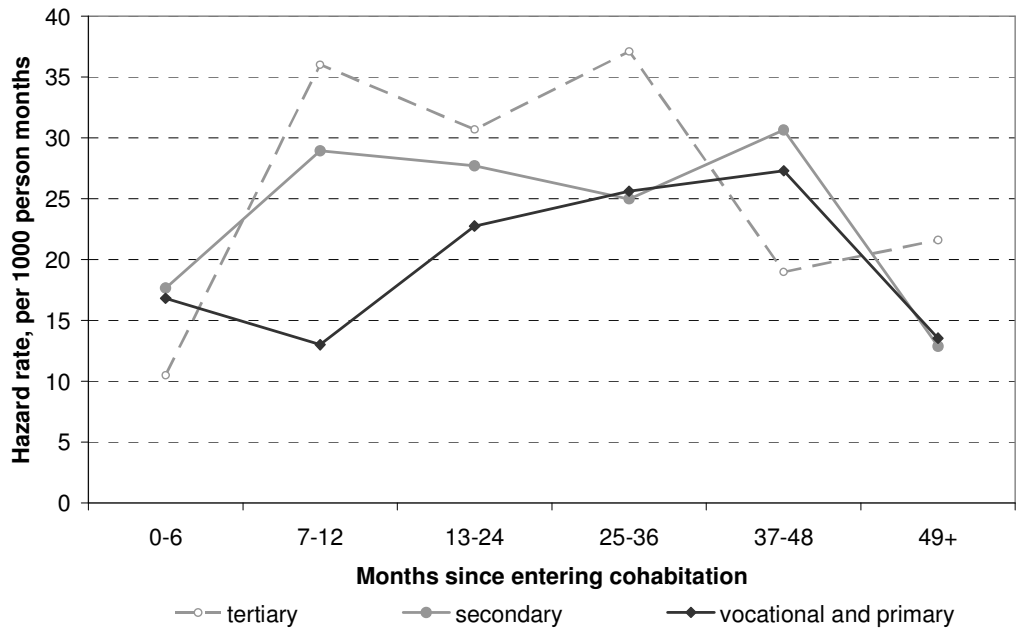

Note: The figure refers to women born 1966-1981. The risks are standardised for current age, calendar year, parity-and-pregnancy status, place of residence, and mother's and father's educational levels.

Source: author's computations. 
Matysiak: Is Poland really 'immune' to the spread of cohabitation?

Nonetheless, a two-way interaction between educational level and calendar period reveals an important change in the educational gradient in the patterns of first union formation. While in the second half of the 1990s the rise in the risk of entry into a cohabitation was most pronounced among the less educated, in the following years it was definitely the secondary and tertiary educated who increased their interest in this type of union (Figure 3). A marked rise in the risk of entering into an informal union was also recorded among persons 'in education'. Furthermore, women with secondary and university degrees experienced the strongest decline in marriage intensity after the episode of cohabitation (Figure 4). Overall, these findings point out that Poland started to experience a diffusion of cohabitation to better educated social strata.

\section{Figure 3: Trends in the (standardised) relative risks of entering cohabitation,} by educational level. Poland 1985-2006. Single decrement model

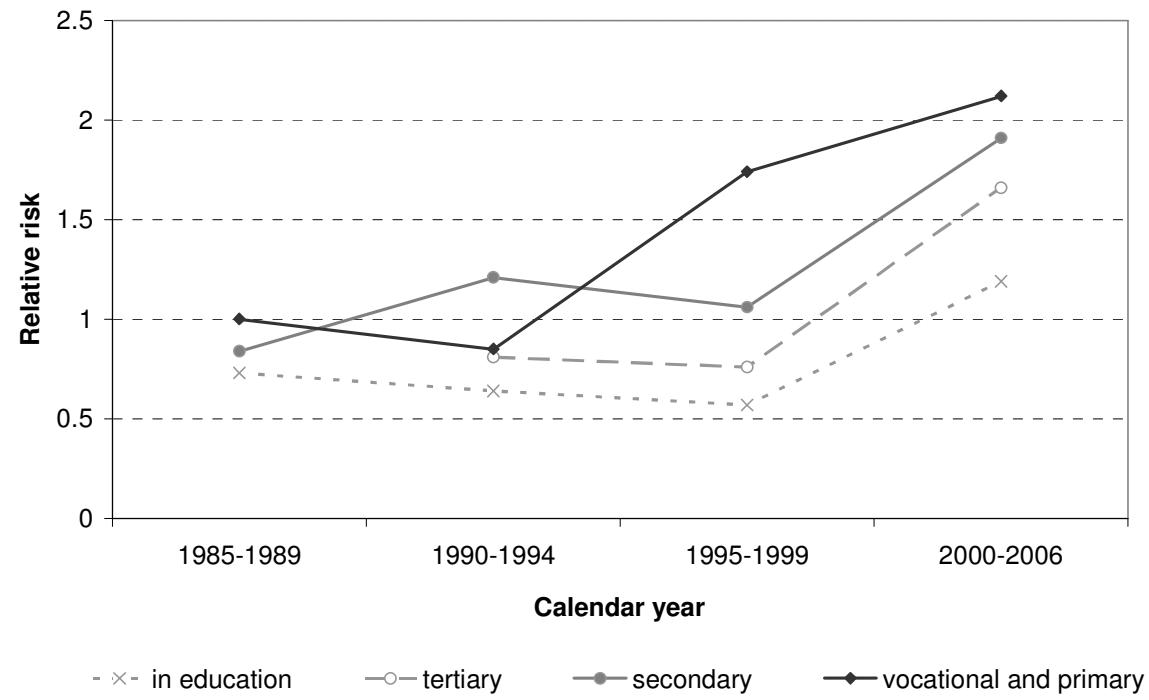

Note: The figure refers to women born 1966-1981. The risks are standardised for current age, woman's educational level, parity-andpregnancy status, place of residence, and mother's and father's educational levels

Source: author's computations. 
Figure 4: $\quad$ Trends in the (standardised) relative risks of entering marriage during cohabitation, by educational level. Poland 1985-2006

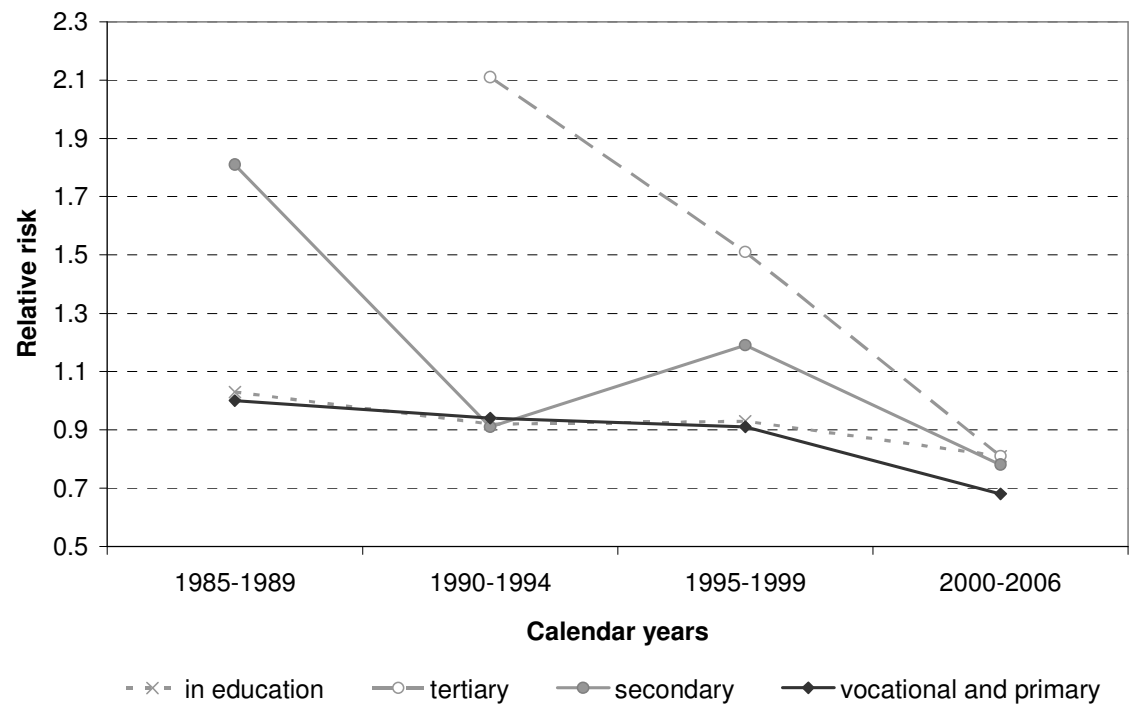

Note: The figure refers to women born 1966-1981. The risks are standardised for current age, parity-and-pregnancy status, place of residence, mother's and father's educational levels, and duration of cohabitation.

Source: author's computations.

\subsection{Cohabitation as a family arrangement?}

As expected, pregnancy boosts the risk of entering a union, particularly marriage, among the non-partnered women. It is notable that also among the cohabiting women the arrival of a pregnancy elevates the intensity of marriage formation (Table 3). This suggests that cohabitation does not function as a family arrangement in Poland and that parenthood is still strongly tied with marriage. Neither was any clear temporal change in the risk of converting cohabitation into marriage upon the occurrence of a pregnancy observed on the basis of the two-way interaction between calendar time and parity-andpregnancy status (Figure 5). Consequently, we have no reasons to claim that acceptance of cohabitation as appropriate environment for childbearing has increased. 
Matysiak: Is Poland really 'immune' to the spread of cohabitation?

Table 3: $\quad$ Relative risks for parity-and-pregnancy status in single decrement models

\begin{tabular}{|c|c|c|c|}
\hline & \multicolumn{2}{|c|}{ Mode of union entry ${ }^{\text {a) }}$} & \multirow{2}{*}{$\begin{array}{l}\text { Conversion of } \\
\text { cohabitation to } \\
\text { marriage }^{\text {b) }}\end{array}$} \\
\hline & cohabitation & direct marriage & \\
\hline \multicolumn{4}{|l|}{ Parity-and-pregnancy status } \\
\hline childless and non-pregnant & 1 & 1 & 1 \\
\hline childless and pregnant & 6.11 & 19.81 & 6.18 \\
\hline mother & 1.88 & 2.35 & 0.61 \\
\hline
\end{tabular}

Notes: ${ }^{\text {a) }}$ - standardized for current age, calendar period, parity-and-pregnancy status, place of residence, mother's and father's educational levels; ${ }^{\text {b) }}$ standardized for current age, calendar period, parity-and-pregnancy status, place of residence, mother's and father's educational levels and union duration.

Source: author's computations.

Figure 5: Trends in the (standardised) relative risks of entering marriage after cohabitation, by parity-and-pregnancy status. Poland 1985-2006

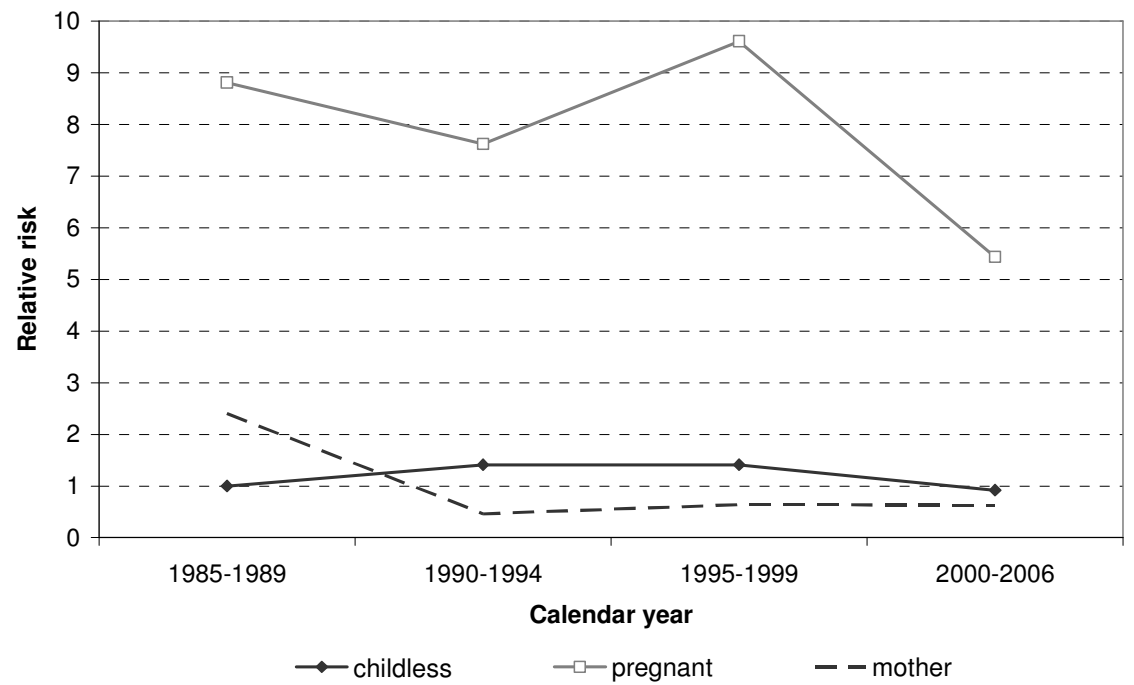

Note: The figure refers to women born 1966-1981. The risks are standardised for current age, woman's educational level, place of residence, mother's and father's educational levels, and duration of cohabitation.

Source: author's computations. 


\section{Conclusions and discussion}

In their overview of the changes in partnership behaviour in Europe Sobotka and Toulemon claim Poland to be 'immune' to the spread of cohabitation, together with Romania and Southern European countries (Sobotka and Toulemon 2008: 100). This conclusion is fully in line with the common belief about cohabitation in Poland itself (e.g., Kwak 2005, Fihel 2005) and it had been so far fully justified given the available data on cohabitation in Poland. These data come exclusively from cross-sectional surveys. They yield a proportion of consensual unions among the total number of unions at $1.4-4.9 \%$.

In this study we demonstrated that the available cross-sectional data clearly underestimate the incidence of cohabitation in Poland. Although consensual unions are still less popular when compared with other European countries, it turns out that Poland is not as 'immune' to the spread of cohabitation as it is commonly believed. This conclusion is drawn on the basis of recent retrospective data providing detailed information on partnership histories. These data show that Polish women born 19661981 have been increasingly choosing cohabitation as their first union. This upward trend in the incidence of consensual unions has been taking place since the early 1990s, being accompanied by a decline in direct marriage. Although the latter is still the most popular way of forming a first union, in the years 2004-2006 entries to cohabitation constituted already about one third of all first union entries. Furthermore, our study has revealed clear signs of the spread of cohabitation across various social strata.

It is apparent that consensual unions in Poland are mostly formed by the least educated. The incidence of cohabitation in the lowest social strata increased sharply during the 1990s. Furthermore, consensual unions formed by the least educated last the longest before they are converted into marriage. Since the early 2000s another group of cohabitants has been emerging, however. It consists of the secondary and tertiary educated. The incidence of cohabitation in this social group is still lower, and the consensual unions formed by the better educated are shorter; nonetheless, we found a clear increase in the intensity of entering cohabitation as well as a decline in the risk of converting a non-marital to a marital union in the higher social strata.

Given these outcomes, we conclude that Poland has reached the second stage of cohabitation diffusion. This conclusion is consistent with that of Mynarska and Bernardi (2007) who arrived at a similar finding using qualitative data. Informal unions have become more popular among the various social strata. Still, it is apparent that they are perceived as a prelude to marriage, a trial period, and are not accepted as an appropriate environment for parenthood. What Poles are opting for is a commitment that they believe is only achieved through marriage (Mynarska and Bernardi 2007: 546). Further research on cohabitation, particularly on younger cohorts, born in the 
Matysiak: Is Poland really 'immune' to the spread of cohabitation?

1980s, would enable a better understanding of the transition in partnership behaviors in Poland.

\section{Acknowledgements}

This study was conducted thanks to the financial support from the Max Planck Institute for Demographic Research (MPIDR), Rostock, Germany. It was inspired by a series of papers written by Prof. Jan M. Hoem and colleagues on first union formation and traces of Second Demographic Transition in Central and Eastern European countries. We are grateful to Prof. Jan M. Hoem for his support in conducting the joint analysis of entry into cohabitation versus direct marriage as well as for his remarks provided to this paper. Furthermore, we highly appreciate the comments of Monika Mynarska, Marta Styrc, and the two anonymous reviewers of Demographic Research. 


\section{References}

Andersson, G. and Philipov, D. (2002). Life-table representations of family dynamics in Sweden, Hungary and 14 other FFS countries: A project of description of demographic behaviour. Demographic Research 7(4): 67-144. doi:10.4054/DemRes.2002.7.4.

Baizán, P., Aassve, A., and Billari, F.C. (2003). Cohabitation, marriage, and first birth: The interrelationship of family formation events in Spain. European Journal of Population 19(2): 147-169. doi:10.1023/A:1023343001627.

CSO (2003). National Census 2002. Population. State and demographic-social structure. Warsaw: Central Statistical Office.

De Feijter, H. (1991). Voorlopers bij demografische veranderingen. NIDI Reports No. 22, The Hague: Netherlands Interdisciplinary Demographic Institute.

European Social Survey (2006). www.europeansocialsurvey.org/ [data retrieved in February 2008].

Fihel, A. (2005). Consensual unions in Poland: an analysis of the 2002 Population Census. Studia Demograficzne 1(147): 104-120.

Fokkema, T., de Valk, H., de Beer, J., and Van Duin, C. (2008). The Netherlands: Childbearing within the context of a "Poldermodel" society. Demographic Research 19(21): 743-794. doi:10.4054/DemRes.2008.19.21.

Hantrais, L. (2005). Living as a family in Europe. In: Hantrais, L., Philipov, D., and Billari, F.C. (eds.). Policy Implications of Changing Family Formation. Strasburg: Council of Europe Publishing: 117-181.

Haskey, J. (2001). Demographic aspects of cohabitation in Great Britain. International Journal of Law, Policy and Family 15(1): 51-67. doi:10.1093/lawfam/15.1.51.

Hoem, J.M., Kostova, D., Jasilioniene, A., and Muresan, C. (forthcoming). Traces of the Second Demographic Transition in four selected countries in Central and Eastern Europe: Union formation as a demographic manifestation. European Journal of Population.

Hoem, J.M., Kostova, D., Jasilioniene, A., and Muresan, C. (2009). The structure of recent first-union formation in Romania. Romanian Journal of Population Studies 5(1): 33-44. 
Hoem, J.M. and Kosotva, D. (2008). Early traces of the second Demographic Transition in Bulgaria: A joint analysis of marital and non-marital union formation, 19602004. Population Studies 62(3): 259-271. doi:10.1080/00324720802313256.

Kajcińska, B. (2008). Badanie retrospektywne 'Biografie zawodowe, rodzinne i edukacyjne' - analiza podstawowych rozkładów zmiennych demograficznoekonomicznych (Employment, Family and Education Survey - descriptive analysis of socio-demographic characteristics of respondents). Interim report. Warsaw: Institute of Statistics and Demography, Warsaw School of Economics.

Kiernan, K. (2002). Cohabitation in Western Europe: trends, issues and implications. In: Booth, A. and Crouter, A. (eds.): Just Living Together: implications of cohabitation on families, children and social policy. New York: Lawrence Erlbaum Associates: 3-31.

Kotowska, I.E., Abramowska, A., Balcerzak-Paradowska, B., Kowalska, I., Muszyńska, M., and Wróblewska, W. (2003). Polityka ludnościowa - cele, rozwiązania, opinie (Population Related Policy - Goals, Measures, Opinions). Research report from the Population Policy Acceptance Study [unpublished manuscript]. Warsaw: Institute of Statistics and Demography, Warsaw School of Economics.

Kotowska, I.E., Jóźwiak, J., Matysiak, A., and Baranowska, A. (2008). Poland: Fertility decline as a response to profound societal and labour market changes? Demographic Research 19(22): 795-854. doi:10.4054/DemRes.2008.19.22.

Koytcheva, E. and Philipov, D. (2008). Bulgaria: Ethnic differentials in rapidly declining fertility. Demographic Research 19(13): 361-402. doi:10.4054/DemRes.2008.19.13.

Kwak, A. (2005). Rodzina w dobie przemian. Matżeństwo i kohabitacja. (Family in the Age of Change. Marriage and Cohabitation). Warsaw: Żak.

Mynarska, M. and Bernardi, L. (2007). Meanings and attitudes attached to cohabitation in Poland: Qualitative analyses of the slow diffusion of cohabitation among the young generations. Demographic Research 16(17): 519-554. doi:10.4054/DemRes.2007.16.17.

Nazio, T. and Blossfeld, H.P. (2003). The diffusion of cohabitation among young women in West Germany, East Germany and Italy. European Journal of Population 19: 47-82. doi:10.1023/A:1022192608963.

Pongrácz, M. and Spéder, Z. (2008). Attitudes towards forms of partnership. In: Höhn, C., Avramov, D., and Kotowska, I.E. (eds.) People, Population Change and 
Policies: Lessons from the Population Policy Acceptance Study. Volume 1. Berlin: Springer: 93-112.

Prinz, C. (1995). Cohabiting, Married or Single. England: Avebury.

Prskawetz, A., Sobotka, T., Buber, I., Engelhardt H., and Gisser, R. (2008). Austria: Persistent low fertility since the mid-1980s. Demographic Research 19(12): 293-360. doi:10.4054/DemRes.2008.19.12.

Rosina, A. and Fraboni, R. (2004). Is marriage losing its centrality in Italy? Demographic Research 11(6): 149-172. doi:10.4054/DemRes.2004.11.6.

Sigle-Rushton, W. (2008). England and Wales: Stable fertility and pronounced social status differences. Demographic Research 19(15): 455-502. doi:10.4054/DemRes.2008.19.15.

Slany, K. (2002). Alternatywne formy życia matżeńsko-rodzinnego $w$ ponowoczesnym świecie. (Alternative forms of marital-family settings in the post-modern world). Cracow: Nomos.

Sobotka, T. and Toulemon, L. (2008). Overview Chapter 4: Changing family and partnership behaviour: Common trends and persistent diversity across Europe. Demographic Research 19(6): 85-138. doi:10.4054/DemRes.2008.19.6.

Sobotka, T., Št’astná, A., Zeman, K., Hamplová, D., and Kantorová, V. (2008). Czech Republic: A rapid transformation of fertility and family behaviour after the collapse of state socialism. Demographic Research 19(14): 403-454. doi:10.4054/DemRes.2008.19.14.

Sobotka, T. (2008). Overview Chapter 6: The diverse faces of the Second Demographic Transition in Europe. Demographic Research 19(8): 171-224. doi:10.4054/DemRes.2008.19.8.

Spéder, Z. (2005). The rise of cohabitation as first union and some neglected factors of recent demographic developments in Hungary. Demográfia, English Edition 48: 77-103.

Stankuniene, V. and Maslauskaite, E. (2008). Family transformations in the postcommunist countries: Attitudes toward changes and the ideational shift. In: Höhn, Ch., Avramov, D. and Kotowska, I.E. (eds.). People, Population Change and Policies: Lessons from the Population Policy Acceptance Study. Volume 1. Berlin: Springer: 113-137.

Trost, J. (1978). A renewed social institution: non-marital cohabitation. Acta Sociologica 21(4), 303-315. 
Matysiak: Is Poland really 'immune' to the spread of cohabitation?

Villeneuve-Gokalp, C. (1991). From marriage to informal union: recent changes in the behaviour of French couples. Population: An English Selection 3: 81-111. 